\title{
Mutual Fund Trading Pressure: Firm-Level Stock Price Impact and Timing of SEOs
}

\section{Citation}

Khan, Mozaffar, Leonid Kogan, and George Serafeim. "Mutual Fund Trading Pressure: FirmLevel Stock Price Impact and Timing of SEOs." Journal of Finance 67, no. 4 (August 2012): 13711395.

\section{Published Version}

10.1111/j.1540-6261.2012.01750.x

\section{Permanent link}

http://nrs.harvard.edu/urn-3:HUL.InstRepos:12175236

\section{Terms of Use}

This article was downloaded from Harvard University's DASH repository, and is made available under the terms and conditions applicable to Open Access Policy Articles, as set forth at http:// nrs.harvard.edu/urn-3:HUL.InstRepos:dash.current.terms-of-use\#OAP

\section{Share Your Story}

The Harvard community has made this article openly available.

Please share how this access benefits you. Submit a story.

Accessibility 


\title{
Mutual Fund Trading Pressure: Firm-Level Stock Price Impact and Timing of SEOs
}

\author{
MOZAFFAR KHAN, LEONID KOGAN, and GEORGE SERAFEIM*
}

\begin{abstract}
We use price pressure resulting from purchases by mutual funds with large capital inflows to identify overvalued equity. This is a relatively exogenous overvaluation indicator as it is associated with who is buying - buyers with excess liquidity - rather than what is being purchased. We document substantial stock price impact associated with purchases by high-inflow mutual funds, and find the probability of an SEO, insider sales, and the probability of a stock-based acquisition increase significantly in the four quarters following the mutual fund buying pressure. These results provide new evidence that firm managers are able to identify and exploit overvalued equity.
\end{abstract}

\footnotetext{
*Khan is at the Carlson School of Management, University of Minnesota. Kogan is at the MIT Sloan School of Management. Serafeim is at Harvard Business School. We thank Gordon Alexander, Jeff Callen, John Core, John DeTore, Campbell Harvey (Editor), Hai Lu, Krishna Palepu, Ricardo Reis, Jay Ritter, Sugata Roychowdhury, Ross Watts, Jeffrey Wurgler (AFA discussant), an anonymous referee and associate editor, and seminar participants at the Harvard Business School, London School of Economics, MIT, University of Minnesota, and the AFA Atlanta 2010 meetings for valuable comments.
} 
Seasoned equity offerings (SEOs) have been widely studied in the literature, with little emerging consensus on their determinants and economic consequences. Proposed determinants of SEOs include capital investments, refinancing, liquidity squeezes, corporate control, stock market microstructure and timing by managers with private information that their stock is overvalued (Loughran and Ritter (1995, 1997), Graham and Harvey (2001), Baker and Wurgler (2002)). In this paper we propose a novel approach to testing the market-timing motive for SEOs, and provide evidence of SEO timing.

The main empirical challenge in tests of SEO timing is identifying overvalued firms. Prior studies examining market timing typically use high market-to-book ratios or high past returns as identifiers of overvaluation. However, these studies "continue to be hotly debated" (Baker, Ruback, and Wurgler (2007)) because, as described in detail in the next section, traditional indicators of overvaluation are correlated with other determinants of SEOs. We respond to this debate in the literature by identifying a setting in which overvaluation is relatively exogenous to the firm. In particular, we identify overvalued stocks as those subject to substantial buying pressure by mutual funds experiencing large capital inflows, but not subject to widespread buying pressure by other mutual funds, and refer to these as stocks subject to Inflowdriven Buying Pressure (IBP). In this setting, the overvaluation is associated with who is buying - mutual funds with excess liquidity - rather than by what is being purchased.

Mutual funds with large capital inflows are eager to invest the cash since stockpiling cash makes it difficult for them to outperform their benchmarks (Coval and Stafford (2007)) and since they may be precluded by their investment mandate from holding large cash balances. This 
excess liquidity is channeled into a narrow set of stocks since mutual funds follow specialized investment strategies (i.e., face restricted investment opportunity sets or IOS), and they likely face diminishing marginal investment prospects. Consistent with restricted IOS and diminishing marginal investment prospects, we document that the average number of stocks held by mutual funds in the top capital flow decile is 107 , which is a small fraction of the universe of stocks. Further, there is a monotonic positive relation between mutual fund flows and the proportion of existing positions expanded by these funds. Funds with higher inflows expand more of their existing positions as opposed to initiating new positions; and in particular, 39\% of the existing positions of funds in the top flow decile are expansions of previously held positions. Funds with higher inflows have about the same proportion of newly initiated holdings as other funds. This is in contrast to a positive relation between fund flows and initiations that would be expected if fund IOS and investment prospects were unrestricted.

We expect inflow-driven mutual fund buying pressure to result in upward stock price pressure if individual stocks have downward-sloping demand curves. To identify overvaluation associated with mutual fund IBP rather than with fundamental information about the firms, we require IBP stocks to meet two ex ante conditions: (i) they are subject to buying pressure by mutual funds in the top flow decile, and (ii) they are not subject to buying pressure by mutual funds in other flow deciles. Using these criteria we identify approximately $1.5 \%$ of all mutual fund trades as IBP. We then document that IBP stocks have average prior-year returns of $49 \%$ and experience a cumulative decline in market-adjusted returns of $10 \%$ over the six quarters subsequent to the buying pressure quarter, consistent with overvaluation due to IBP. In contrast, 
stocks subject to widespread buying pressure by mutual funds other than those in the top decile of capital flows (WBP stocks) have average prior-year returns of $32 \%$ and experience a cumulative decline in market-adjusted returns of $2.8 \%$ over the subsequent six quarters, consistent with widespread buying being driven more by firm-specific information. ${ }^{1}$ The large abnormal return reversion of IBP stocks after buying pressure is not consistent with alternative explanations that inflow-driven buying is informed, or that high-inflow fund managers are smart stock pickers.

Identifying equity with pronounced and sustained overvaluation (IBP stocks) is a precondition to our main objective, testing the SEO timing theory. If managers privately identify overvaluation and time SEOs to exploit the overvaluation, we expect IBP-affected firms to exhibit a higher likelihood of SEOs relative to all firms that are not overvalued. We find 172 SEOs associated with IBP stocks, collectively accounting for $\$ 23 b$ of new equity. These SEOs represent $5.2 \%$ by number, and $6.6 \%$ by dollar value, of all SEOs in our sample. We test the timing hypothesis by estimating a Logit model of SEO choice that controls for a number of determinants of SEOs, including prior returns and the market-to-book ratio. In addition, we construct a number of matched samples in which we first match IBP firms to other firms on selected firm characteristics, and then compare SEO probabilities in the "treatment" and "control" samples in the four quarters following IBP. In all tests, the probability of an SEO following IBP stock-quarters is significantly higher, ranging from $30 \%$ to $84 \%$ higher probability. This finding suggests that firm managers identify overvaluation and time SEOs.

\footnotetext{
${ }^{1}$ In our formal tests, when comparing the behavior of IBP stocks to the relevant reference groups, we control for various firm characteristics such as prior returns.
} 
To corroborate the evidence on SEO timing we test two other predictions. First, if IBP firms are overvalued we expect an increase in insider sales. We therefore test for increased insider sales in the four quarters following IBP. We estimate a multiple regression model of insider sales (e.g., Rozeff and Zaman (1998), Piotroski and Roulstone (2005), Jenter (2005)), and also test for differences in mean insider sales in matched samples. In all tests, we find significantly higher insider sales in the four quarters following IBP, ranging from 5.3\% to $9.3 \%$ higher sales ratios. An increase in insider sales of IBP stocks is not consistent with alternative explanations that inflow-driven mutual fund purchases are informed. However, it is consistent with our hypothesis that excess fund liquidity, combined with funds' restricted IOS and diminishing marginal investment prospects, is associated with overvalued purchases.

Second, if IBP firms are overvalued we expect them to exhibit a higher likelihood of stock-based acquisitions in the four quarters following IBP. Shleifer and Vishny (2003), Jensen (2005), and Rhodes-Kropf, Robinson and Viswanathan (2005) suggest that overvaluation is associated with stock-based acquisitions and increases the probability of deal initiation or of completion of previously initiated deals. We find 268 acquisitions associated with IBP stocks, collectively accounting for $\$ 309 \mathrm{~b}$ of transactions. These acquisitions represent 3.9\% by number, and $9 \%$ by dollar value, of all acquisitions in our sample. We test the timing prediction by estimating a Logit model as well as by conducting tests of differences in acquisition frequency in matched samples. In most tests of M\&A probability in the four quarters following IBP, we find that the probability of an acquisition is significantly higher, ranging from $19 \%$ to $35 \%$ higher probability. 
Our findings collectively support the hypothesis that managers exploit "windows of opportunity” (Loughran and Ritter $(1995,1997))$ presented by overpricing of their firms' equity to time the market. Our findings are also consistent with a broad class of models in which capital markets are imperfect but managers are able to identify price dislocations (see Baker, Ruback, and Wurgler (2007) for a review). The equity market timing theory has implications for external financing choice, for the firm's capital structure if the impact of timing is persistent, for corporate governance in terms of allowing managers discretion to exploit or ignore market price signals that differ from their private assessment of value, and for understanding determinants of insider trading.

We note as a caveat that we establish an association, rather than a causal relation, between buying pressure and overvaluation. A causal interpretation is consistent with our collective empirical evidence as described above, but without a rigorous proof of causality we cannot rule out potential alternative explanations for the association.

The rest of this paper proceeds as follows. Section I briefly describes our setting and reviews the prior literature on SEO timing and price pressure. Section II describes the identification of overvalued stocks as a result of IBP by mutual funds. Section III describes tests of SEO timing, insider sale timing, and M\&A timing. Section IV discusses a number of sensitivity tests. Section V concludes with a summary, discussion of some implications of our findings, and suggestions for future research. 


\section{The Setting}

A number of papers have examined whether managers time the market when issuing equity. The main empirical challenge is to identify mispriced stocks, and prior authors have used ex ante and ex post methods to infer mispricing (Baker, Ruback, and Wurgler (2007)).

Ex ante methods include using a measure of fundamental value scaled by market value, such as the market-to-book ratio, or using prior returns to identify overvalued stocks. As emphasized in Baker, Ruback, and Wurgler (2007), both measures are difficult to interpret. For example, measuring fundamental value is difficult since accounting book values are based on historical costs and subject to discretionary managerial accounting choices. Further, the marketto-book ratio is correlated with many firm characteristics that may drive financing policy, so high market-to-book ratios do not necessarily indicate overvaluation that can be exploited by market timers. Prior returns as a measure of mispricing face similar difficulties in interpretation. Firms with high prior returns may have discovered valuable growth opportunities and thus harvesting these opportunities, rather than market timing, could drive the issuance decision.

Ex post methods rely on reversion in future abnormal returns to infer overvaluation. For example, tests of long-horizon stock return performance following SEOs find underperformance, suggesting that issuance occurred when the stock was overpriced. One challenge to this interpretation is that risk changes may be associated with SEOs. For example, Eckbo, Masulis, and Norli (2000) suggest that equity issuance lowers leverage and in turn systematic risk, leading to lower future returns. 
In this paper we use ex ante information to identify overvalued stocks, but our identifier is an event rather than a firm characteristic. In particular, the event is large uninformed buying pressure by mutual funds with large capital inflows. We document that this event is associated with large abnormal returns and subsequent return reversion, and argue that this event is likely exogenous to the firm since it is associated with who is buying - buyers with excess liquidity rather than with what is being bought. We discuss our identification method in detail in the next section.

Prior empirical evidence of short-lived price pressure in equity markets is presented in Kraus and Stoll (1972), Harris and Gurel (1986), Shleifer (1986), and Mitchell, Pulvino, and Stafford (2004), and evidence of slightly longer-lived price pressure of a few weeks is presented in Greenwood (2005). However, relatively short-lived price pressure precludes testing the equity market timing theory. Evidence of price pressure due to flow-driven mutual fund trading, with prices persistently reverting over a few quarters, is presented in Coval and Stafford (CS, 2007), but our paper differs in a number of ways: (i) our objective is to test the equity market timing theory, while CS do not test the timing theory, (ii) our focus is on inflow-driven buying and we offer a story for the resulting price pressure, while CS focus on and offer a story for outflowdriven firesales, and (iii) our mispricing identifier differs in that our mispricing candidates are stocks subject to buying pressure by funds in the top flow decile (first condition) but not subject to buying pressure by other funds (second condition). The mispricing identifier in CS imposes our first, but not our second, condition. 
Consistent with our results, Frazzini and Lamont (2008) use mutual fund flows as a measure of individual investor sentiment and find that high sentiment (or dumb money) predicts low future returns. They also report that high sentiment is associated with increases in shares outstanding in the next three years. Our paper differs in a number of ways: (i) our focus is on the timing of SEOs and we provide extensive tests of the SEO timing hypothesis, (ii) we show that insider sales are timed to exploit overvaluation, (iii) we show that stock-based acquisitions are timed to exploit overvaluation, and (iv) we show that managers respond to overvaluation in a more timely manner, within four quarters of being affected by IBP.

Our paper is also related to Chen et al. (2007), who examine whether hedge funds exploit mutual fund trading pressure through front-running. We examine whether a different group of market participants, firm managers, exploit IBP through SEOs, insider sales, and M\&A. Consistent with Chen et al. (2007), our results suggest that "sophisticated" market participants are able to identify this particular source of mispricing (price pressure due to inflow-driven mutual fund purchases), ${ }^{2}$ although our data allow us to provide more direct evidence since we are able to match SEOs, insider sales, and M\&A to IBP-affected stocks.

\section{Mutual Fund Trading Pressure and Stock Price Impact}

Mutual funds experiencing large capital inflows face the unique challenge of excess liquidity: quickly finding productive opportunities for the new capital. Stockpiling cash is likely against their charter, and is also likely to increase tracking error with respect to their all-equity

\footnotetext{
${ }^{2}$ Anecdotal evidence suggests large investment banks also keep track of mutual fund flow-driven price pressure.
} 
benchmarks. Since funds follow specialized investment strategies we do not expect the excess cash to be invested widely in the universe of stocks. Rather, funds' restricted IOS and diminishing marginal investment prospects are likely to result in the excess cash being channeled into a narrow set of stocks and creating buying pressure in some stocks. We expect the buying pressure by such funds to dislocate prices of the stocks they choose to buy (e.g., Coval and Stafford (2007)).

For each stock held by mutual funds, we form a measure of trading pressure as follows. First, we define mutual fund flows as

$$
\text { Flow }_{j, s}=\left\{T A_{j, s}-T A_{j, s-1}\left(1+R_{j, s-1}\right)\right\} / T A_{j, s-1}
$$

where $T A$ is total net assets of mutual fund $j$ in month $s$, and $R$ is the monthly return for fund $j$ in month $s$. We sum the monthly flows each quarter to obtain the quarterly flow, flow $w_{j, t}$, of mutual fund $j$ in quarter $t$. Mutual funds' monthly total net assets and returns of mutual funds are obtained from CRSP, and quarterly mutual fund holdings are obtained from Thomson Financial. Mutual funds are required to report their holdings semi-annually, but approximately $60 \%$ of funds report their holdings quarterly. To calculate quarterly changes in holdings, we retain only contiguous fund-quarters in our sample. In addition, we only consider open-ended U.S. equity funds and eliminate funds with investment objective codes indicating bonds and preferred stocks, international stocks, metals, and municipal bonds from our sample. 


\section{[TABLE I HERE]}

Table I shows quarterly flows, prior-year returns, total number of holdings, and percent of holdings that were expanded or initiated by mutual fund flow decile for 63,426 fund-quarters from 1990 to 2007 . The table shows a large spread in flows, ranging from $40.3 \%$ for the top decile to $-17 \%$ for the bottom decile. Prior-year fund returns decrease monotonically from $16.6 \%$ for the top decile to $6.1 \%$ for the bottom decile. This confirms evidence in the prior literature that (i) fund flows vary monotonically with past fund performance, and (ii) the flowperformance relation is asymmetric in that inflows due to good past performance are much larger in magnitude than outflows due to poor past performance (Ippolito (1992), Chevalier and Ellison (1997), Sirri and Tufano (1998)).

Table I also shows a roughly inverted U-shaped relation between fund flows and number of holdings, with funds in the top flow decile holding on average 107 stocks. Funds with extreme flows have fewer holdings on average than funds in the middle deciles of flows, suggesting that for some funds extreme performance may be associated with more concentrated positions. The table also shows a monotonic positive relation (weakly U-shaped relation) between fund flow decile and the percent of holdings expanded (initiated). For funds in the top flow decile, $39 \%$ of the existing holdings have been expanded from the prior quarter, while $19 \%$ of their existing holdings are new initiations (the remaining $42 \%$ of holdings have been either maintained or reduced from the prior quarter). These results are consistent with mutual funds 
having restricted IOS and diminishing marginal investment prospects for each additional inflow dollar.

We calculate trading pressure for stock $i$ in quarter $t$ as

$$
\begin{gathered}
\text { Pressure }_{i, t}= \\
\left.\qquad \sum_{j}\left(\max \left(0, \Delta \text { holding }_{j, i, t}\right) \mid \text { flow }_{j, t}>90^{\text {th }} \text { percentile }_{t}\right)-\sum_{j}\left(\max \left(0,-\Delta \text { holding }_{j, i, t}\right) \mid \text { flow }_{j, t}<10^{\text {th }} \text { percentile }_{t}\right)\right\} \\
\text { /Shares Outstanding } \\
i, t-1
\end{gathered}
$$

where $i$ indexes the stock, $j$ indexes the mutual fund, and $t$ indexes the calendar quarter. This measure is similar to those used in Coval and Stafford (2007) and Chen et al. (2007). ${ }^{3}$ Intuitively, trading pressure is interpreted as buying pressure when funds with large inflows (top decile of flow in quarter $t$ ) are net buyers of the stock, and as selling pressure when funds with large outflows (bottom decile of flow in quarter $t$ ) are net sellers of the stock. In a sense, Pressure is a measure of excess demand from mutual funds with large capital flows.

To distinguish flow-motivated trading from potentially information-motivated trading, we calculate unforced pressure for stock $i$ in quarter $t$ as

$$
\text { UPressure }_{i, t}=\left\{\sum_{j} \Delta \text { holding }_{j, i, t} \mid 10^{\text {th }} \text { percentile }_{t} \leq \text { flow }_{j, t} \leq 90^{\text {th }} \text { percentile }_{t}\right\} / \text { Shares }_{\text {Outstanding }}, t,-1 \quad .
$$

\footnotetext{
${ }^{3}$ Results are robust to using average lagged quarterly trading volume over the prior two quarters as the denominator in calculating Pressure, as well as to excluding the max function, as reported in the Internet Appendix. The Internet Appendix is located on the Journal of Finance website at http://www.afajof.org/supplements.asp.
} 
This variable captures net trading activity in a stock by mutual funds in the middle eight deciles of flows, or widespread net trading. Information-driven purchases are identified as stocks in the top decile of UPressure. The variable UPressure is similar to measures used in Lakonishok, Shleifer, and Vishny (1992) and Wermers (1999) to identify mutual fund demand imbalances.

We sort stock-quarters into deciles of Pressure and UPressure, and identify IBP stocks as those in the top decile of Pressure but in the middle three deciles (deciles four, five, and six) of UPressure. $^{4}$ In other words, IBP stocks are those that are subject to large buying pressure by mutual funds with extreme inflows, but that are not subject to widespread net trading pressure by other mutual funds. IBP stocks are our overvaluation candidates. To examine whether the overvaluation of IBP stocks is driven by inflow-driven mutual fund buying pressure rather than by mutual fund buying pressure generally, we contrast the abnormal return pattern of IBP stocks with that of stocks in the top decile of UPressure. We refer to stocks in the top decile of UPressure as Widespread Buying Pressure (WBP) stocks.

\section{[TABLE II HERE]}

Table II shows stock-level means of all variables for three samples: the full sample of stocks used in our tests, IBP stocks, and WBP stocks. We obtain accounting data from Compustat Fundamentals Quarterly. We exclude all securities that do not have a share code of

\footnotetext{
${ }^{4}$ Results are robust to intersecting the top Pressure decile with the middle two or middle four UPressure deciles, as reported in Section IV.
} 
10 or 11 in CRSP. Insider trading data are from the Thomson Financial Insider database. The full sample includes 313,750 firm-quarters from 1990 through 2007. The IBP sample consists of 2,515 stock-quarters, and the WBP sample consists of 17,160 stock-quarters, from 1990 through 2007. All variable definitions are presented in the Appendix. Table II shows that IBP and WBP stocks are similar in all characteristics with the exception of prior-year return, which is $49.3 \%$ for IBP stocks and $31.9 \%$ for WBP stocks, and Insider Sale, which is 0.483 for IBP stocks and 0.462 for WBP stocks. The differences in prior year return and Insider Sale are expected if IBP stocks are overvalued. IBP and WBP stocks are also different in terms of Pressure and UPressure, but these differences occur by construction. Finally, both IBP and WBP stocks are different from the full sample of stocks in several dimensions.

\section{[TABLE III HERE]}

Panel A of Table III shows quarterly mean abnormal returns from quarters $t-4$ to $t+6$ for stocks subject to mutual fund buying pressure in quarter $t=0$ (Pressure is calculated in quarter $t=0)$. Abnormal returns are industry-adjusted returns, using the Fama-French equal-weighted 48 industry portfolios. We calculate mean abnormal returns each quarter for the portfolio of IBP and WBP stocks, and use the time series of portfolio abnormal returns for statistical inference to control for cross-sectional correlation (e.g., Fama and MacBeth (1973), Coval and Stafford (2007)). In Panel B of Table III abnormal returns are the alphas, or intercepts, from Fama and French (1993) factor model regressions. IBP and WBP stocks are added to their respective 
portfolios in the quarter following buying pressure and are held for three years or five years. Panel B reports monthly alphas in percentage points.

Panel A of Table III shows that IBP stocks experience significantly positive abnormal returns in buying quarters, followed by persistently negative abnormal returns in subsequent quarters as buying pressure subsides. IBP stocks have cumulative average abnormal returns of $9.82 \%$ ( $p$-value $<0.05)$ from quarters $t+1$ to $t+6$. In contrast, WBP stocks experience small negative abnormal returns after quarter $t=0$, with cumulative average abnormal returns from $t+1$

to $t+6$ of $-2.68 \%$ ( $p$-value $<0.10)$. In Panel B, IBP stocks have statistically significant monthly Fama-French alphas of $-0.36 \%(-0.31 \%)$ for three-year (five-year) holding periods, while WBP stocks have insignificant alphas. The abnormal return reversion for IBP stocks, but not for WBP stocks, is consistent with IBP resulting in overvaluation and WBP being associated with favorable firm-specific information.

\section{[FIGURE 1 HERE]}

Figure 1 shows cumulative average abnormal returns (CAAR) for IBP and WBP stocks. We sum average abnormal returns over consecutive quarters to obtain the CAAR shown in Figure 1. The CAAR patterns in Figure 1 suggest that flow-driven mutual fund purchases result 
in substantial overvaluation, or a shift in the demand curve for a stock. In contrast, widespread buying by mutual funds (non-inflow-driven purchases) does not seem to result in overvaluation. ${ }^{5}$

\section{Main Tests}

Using the IBP stocks identified as overvalued in the previous section, we now turn to our main objective, testing the theory that firms exploit "windows of opportunity" to time SEOs (e.g., Loughran and Ritter (1995, 1997), Graham and Harvey (2001), Baker and Wurgler (2002)). Section A presents tests of SEO timing. To corroborate the inference from Section A, we also test whether insider sales are timed (Section B) and whether stock-based corporate acquisitions are timed (Section $\mathrm{C})$.

\section{A. Timing of SEOs}

We test whether firms identify and exploit the overvaluation associated with mutual fund flow-driven buying pressure by issuing seasoned equity within four quarters of the stock being subject to IBP. We do not examine SEOs contemporaneous with buying pressure to avoid confounding inferences through any reverse causality (i.e., that mutual funds may be buying because firms are issuing equity, rather than the reverse, which is our hypothesis). The prior evidence in the literature suggests that a four-quarter managerial response window allows sufficient time for firms to go to market once they decide to have an SEO. ${ }^{6}$ Before the offering, firms have to register securities with the SEC and may also undertake marketing efforts to

\footnotetext{
${ }^{5}$ Figure 1 depicts firm-level, not mutual fund-level, performance.

${ }^{6}$ Results are robust to using a two-quarter managerial response window as reported in the Internet Appendix.
} 
discover or create demand. Registration can be "traditional," in which case firms register each offering immediately prior to the offering, or "shelf," in which case firms pre-register future potential offerings up to two years in advance and simply take-down these pre-approved offerings as they go to market. Shelf registrations have much shorter registration times. Marketing activities can be full or accelerated, depending on the time taken for demand discovery by sellers and due diligence by potential buyers, and take about two weeks for full marketing and as little as a day for accelerated marketing. Overall, including both registration and marketing times, the average time between the SEC filing date and the offering date for SEOs is about 30 business days (e.g., Gao and Ritter (2010)).

We test our hypothesis of SEO timing by estimating a Logit regression of the issuance decision in quarter $t$, including an indicator dummy for stock-quarters with IBP in any of the four quarters from $t$-4 through $t$-1, which allows a managerial response window of four quarters. Linear regressions of SEO choice on determinants have been estimated in, for example, DeAngelo, DeAngelo and Stulz (2010).

Following the prior literature (e.g., Eckbo, Masulis, and Norli (2000)), we obtain SEO data from the $S D C$ database. After retaining only common stock issuances that trade on the NYSE, AMEX, or NASDAQ, and excluding investment trusts (e.g., REIT's), American Depositary Receipts, utilities (SIC codes 4910-4939), and secondary offerings in which no new shares are issued, we are left with 3,307 SEOs between 1990 and 2007 that have all the required data for our tests. We exclude utilities since the duration of the regulatory approval process limits the ability of utilities to time SEOs in response to temporary overpricing (Eckbo and 
Masulis (1992)). There are 172 SEOs of IBP stocks in the four quarters following IBP, and they collectively account for about $\$ 23 \mathrm{~b}$ of stock issuance. These SEOs represent $5.2 \%$ by number, and $6.6 \%$ by dollar value, of all SEOs in our sample.

[TABLE IV HERE]

Table IV, Panel A, shows the results of Logit regressions for the seasoned equity issuance choice. The dependent variable is one if the firm has a seasoned equity offering (SEO) in quarter $t$, and zero otherwise. The variable Buy Pressure, our main independent variable of interest, is a dummy that equals 1 if the stock was subject to $I B P$ in any of the four quarters from $t$ - 1 through $t-4$, and zero otherwise. The other independent variables are determinants of the equity issuance decision suggested in the literature, and are described further below. The regressions include industry, year, and quarter fixed effects, and standard errors are clustered on both firm and time (two-dimensional clustering) to control for cross-sectional and time-series correlation (Petersen (2009)).

Four regression specifications are reported in Panel A of Table IV. The first specification is estimated over the full available sample of 313,750 stock-quarters. The other three specifications are estimated over smaller samples in which each IBP stock-quarter is matched on industry and two other variables noted at the top of the respective column. For example, in the second column, each IBP stock-quarter is matched with another stock in the same quarter and 
industry and the same asset growth ("first matching variable") and $R O A$ ("second matching variable") quintile. If there are multiple matches, we pick the match closest in the first matching variable. This procedure does not yield a match for some IBP stock-quarters, but we do not relax the matching requirements because this would defeat the purpose of matching. Sufficient sample sizes remain after matching, as noted in the tables. We match on prior returns and bookto-market $(B T M)$ since these are known determinants of SEOs and have also been used as overvaluation indicators (e.g., Jenter (2005)). We match on asset growth and ROA since profitability and growth are likely important determinants of the external financing decision (e.g., Fama and French (2005)). Once the matched sample is obtained, we estimate the Logit over the four quarters following IBP, controlling for other determinants of SEOs as in the full sample Logit. We include these controls because, even in a paired sample, there continues to be heterogeneity in firm characteristics, including heterogeneity in the matching variables across pairs.

The main result in Panel A of Table IV is that the dummy Buy Pressure is significantly positive, with one-tailed $p$-values less than 0.01 in three specifications and less than 0.05 in the fourth specification. This suggests that, ceteris paribus, firms are significantly more likely to have SEOs in the four quarters following flow-driven buying pressure. In terms of economic significance, in the full sample test the probability of an SEO in the four quarters following buying pressure is $58.6 \%$ higher for IBP stocks compared to other stocks. The percent increase in SEO probability is $49.6 \%$ for the BTM-size matched sample, $29.7 \%$ for the return-size matched sample, and $83.5 \%$ for the asset growth-ROA matched sample. These results hold after 
controlling for prior annual returns and the book-to-market ratio (BTM), which have been used as overvaluation indicators in the prior literature. The interpretation is as follows. Consider two firms with similar prior returns and BTM, only one of which is affected by IBP. Under our hypothesis the IBP firm is overvalued, while, as described earlier, high prior returns and low $B T M$ may be interpreted as due to fundamental news. The timing hypothesis suggests that Buy Pressure should load significantly positively after controlling for fundamental news in prior returns and BTM, and the hypothesis is supported in Table IV.

Also in Panel A of Table IV, the probability of issuing equity is significantly increasing in the one-year return in all samples, and significantly decreasing in the book-to-market ratio (BTM) in three samples, consistent with firms issuing equity after they have experienced high returns (e.g., Asquith and Mullins (1986), Loughran and Ritter (1995)) or when their market values are high relative to book values (e.g., Jenter (2005), DeAngelo, DeAngelo, and Stulz (2010)). Leverage loads significantly positively in all samples, consistent with "financially constrained" firms being more "equity-dependent" (e.g., Baker, Stein, and Wurgler (2003)). ROA is significantly negative in all three matched samples, consistent with more profitable firms being less dependent on external financing. Asset growth is significantly positive in three samples, consistent with a need for external capital to finance growth. The change in stock return volatility over the prior year loads significantly negatively in all matched sample regressions, which is consistent, for example, with an increase in volatility delaying an SEO due to the increased basis risk in going to market. The loadings of other variables vary across samples in significance or sign. 
To relax the linearity assumption implicit in the regressions of Panel A, Panel B of Table IV reports SEO frequencies and a test of difference in SEO probabilities for IBP versus matching firms for each of the three matched samples used in Panel A. In all three matched samples, the probability of an SEO in the four quarters following IBP is significantly higher with one-tailed $p$ values less than 0.01, consistent with the evidence in Panel A. For instance, in the return-size matched test, the relative frequency of an SEO is $1.4 \%$ in the matched sample, compared to $1.9 \%$ in the IBP sample, which represents a $38 \%$ increase in SEO frequency. Overall, Table IV provides support for our main hypothesis that firms time equity issuances to exploit exogenous overvaluation.

\section{B. Timing Insider Sales}

If managers identify and exploit price pressure by timing SEOs, we expect them to time their personal sales similarly. This is a powerful test of our hypothesis that mutual fund purchases of stocks we identify as IBP are overvalued and result from funds' restricted IOS and diminishing marginal investment prospects, as opposed to the alternative information hypothesis that IBP stock purchases are due to favorable fundamental information about the firm. We expect insiders to sell more shares in the four quarters following IBP if the IBP stock is overvalued (our hypothesis), but not if their firm faces favorable future prospects (the information hypothesis). The hypothesis is tested by estimating regressions of insider sales in quarter $t$, including an indicator variable for buy pressure as defined earlier.

The power of our test to detect timing by managers is potentially limited by the fact that 
firms frequently restrict insider sales to certain short windows, for example, within three to 12 days after quarterly earnings announcements (Bettis, Coles, and Lemmon (2000)), or require managers to maintain a certain minimum level of holdings. We expect this is unlikely to be an issue because: (i) we examine insider sales over the four quarters following flow-driven buying pressure, not within a narrow window of a few days, and (ii) this limitation biases against our ability to reject a null hypothesis of no change in insider sales.

\section{[TABLE V HERE]}

Panel A of Table V shows results of panel regressions with Insider Sale, the ratio of shares sold to the sum of shares sold and purchased, as the dependent variable. ${ }^{7}$ All trades are open market trades. The regressions include time and industry fixed effects, and standard errors are clustered on both firm and time (two-dimensional clustering). Four regressions are estimated, one for the full sample of 211,227 stock-quarters with all available data, and one each for three matched samples. We match on prior one-year return and size, and on BTM and size, since returns and BTM have been used as overvaluation identifiers in the prior literature, as noted earlier. For the third matched sample we match on size and lagged insider sales to control for individual managers' persistent liquidity and diversification needs. The main result in Panel A of Table V is that the dummy Buy Pressure is significantly positive in all samples with onetailed $p$-values less than 0.01. The coefficient on Buy Pressure is of 0.027 in the full-sample

\footnotetext{
${ }^{7}$ Our dependent variable, the sales ratio, is similar to that in Rozeff and Zaman (1998) and Piotroski and Roulstone
} (2005), who use the purchase ratio, calculated as shares purchased divided by the sum of shares purchased and sold. 
regression. Since the mean of Insider Sale in Table II is 0.4003 , this suggests that insider sales increase by $0.027 / 0.4003=6.9 \%$ in the four quarters following IBP, which is an economically significant magnitude.

Also in Panel A of Table V, Insider Sale is increasing in firm size in all samples, consistent with Seyhun (1986), Rozeff and Zaman (1988), and Core et al. (2006). The variable Insider Sale is significantly positively related to the past one-year return, suggesting that insiders sell relatively more than they purchase when the stock price is high relative to the past. Further, Insider Sale is generally decreasing with the BTM decile in all samples, consistent with Rozeff and Zaman (1998), Piotroski and Roulstone (2005), and Jenter (2005). The BTM decile dummies are labeled BTM1, BTM2, and so on, with BTM1 being low and BTM10 being high book-to-market. We omit BTM10 from the regression and so it is the reference or base decile. This result suggests that insiders at high growth firms sell relatively more than they purchase compared to insiders at value firms, consistent with exit or diversification needs of insiders at high growth firms.

As in Core et al. (2006), we control for insiders' normal propensity to trade with lagged

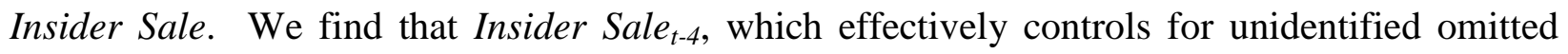
variables in our regression, is significantly positive with $p$-values less than 0.01 in all samples. We also control for the level of insider holdings, Insider Holding, and find that it loads significantly positively with $p$-values less than 0.01 in all samples, suggesting that insiders sell more when they have higher exposure to firm-specific risk through higher holdings.

In Panel B of Table $\mathrm{V}$ we relax the linearity assumption implicit in the regressions of 
Panel A. Panel B reports the mean insider sale ratio for IBP versus matching stocks for each of the three matched samples, as well as $p$-values for a test of difference in means. For each matched sample, insider sales are significantly higher for IBP stocks in the four quarters following IBP, with $p$-values less than 0.01. Overall, the results in Table V align with those reported in Table IV, and suggest that insiders are able to identify overvaluation and hence to time both firm-level equity issuances and insider sales.

\section{Timing Mergers and Acquisitions}

Jensen (2005) suggests that overvalued equity is used as currency to finance stock-based acquisitions. The models in Shleifer and Vishny (2003) and Rhodes-Kropf and Viswanathan (2004) also predict the same, while the empirical evidence in Rhodes-Kropf, Robinson, and Viswanathan (2005) suggests that acquirer overvaluation is higher in completed deals than in failed deals. Hence, if IBP stocks are overvalued, we expect a higher likelihood of stock-based acquisitions in the four quarters following buying pressure because overvaluation can affect both the likelihood of deal initiation as well as the likelihood of completion of previously initiated deals. However, the power of our test is potentially limited if: (i) acquisitions require time and overvaluation diminishes with time, (ii) higher overvaluation than that resulting from flowdriven mutual fund purchases is needed to trigger acquisitions, and (iii) mergers occur primarily in waves, in response to industry-wide rather than firm-specific overvaluation. Our overvaluation indicator is firm-specific (recall that Table III and Figure 2 show industry-adjusted negative abnormal returns for IBP firms after the buying pressure quarter). 
We test for M\&A timing using Logit regressions in which the dependent variable is one if the firm completed an acquisition in quarter $t$, and zero otherwise (Harford (1999) also estimates linear regressions of the M\&A decision). M\&A data comes from the $S D C$ database. We find 268 acquisitions associated with IBP stocks, collectively accounting for $\$ 309 \mathrm{~b}$ of transactions. These acquisitions represent $3.9 \%$ by number, and $9 \%$ by dollar value, of all acquisitions in our sample. The main independent variable of interest in our Logit regressions is the dummy Buy Pressure, defined as previously. We control for prior one-year return and BTM because these have previously been used as overvaluation indicators. We control for cash, ROA, and dividend yield because profitable firms that retain cash are more likely to acquire (e.g., Jensen (1986)). We also control for size and asset growth over the prior year (e.g., Harford (1999)).

Table VI, Panel A, reports results of four Logit regressions, one estimated over the full sample of all available firms, and the other three estimated over matched samples. The dummy Buy Pressure is significantly positive with a $p$-value less than 0.01 in the full-sample Logit, and the coefficient indicates an increase in acquisition probability of $20 \%$. It is also significantly positive with a $p$-value less than 0.05 in the sample matched on asset growth and ROA, with a coefficient indicating an increase in acquisition probability of $24.3 \%$. The dummy Buy Pressure is insignificant in the other two matched samples (return-size and BTM-size). Panel A of Table VI also shows that return, size, and asset growth are significantly positive in all samples as predicted (e.g., Harford (1999)), and BTM is significantly negative as predicted. ROA is significantly positive in the matched sample regressions, consistent with more profitable firms 
being more likely to engage in an acquisition.

\section{[TABLE VI HERE]}

In Panel B of Table VI we relax the linearity assumption implicit in Panel A and report acquisition frequencies, as well as a test of difference in M\&A probabilities for IBP versus matching firms, for each of the three matched samples. IBP firms are significantly more likely to acquire than matched firms, with $p$-values less than 0.01 for the asset growth-ROA and returnsize matched samples, and less than 0.05 for the BTM-size matched sample. The increase in acquisition probability ranges from $18.7 \%$ (BTM-size sample) to $34 \%$ (asset growth-ROA sample). Overall, the evidence in Table VI supports the earlier evidence that firm managers identify and exploit overvalued equity.

\section{Additional Analysis}

In this section we conduct a number of sensitivity tests. We summarize the results below and report all tables as well as additional tests in the Internet Appendix.

(i) Our return-matched tests are designed to address the possibility of a nonlinear relation between prior-year stock returns on the one hand, and SEOs, insider sales, and M\&A on the other. We further address the possibility of a nonlinear relation using dummies for the first nine return deciles, labeled ret10 to ret 90 . For the top return decile, we use percentile dummies 
labeled ret91 to ret 99 . Hence, we simultaneously control for $\operatorname{ret} 10, \ldots$, ret 90, ret $91, \ldots . .$, ret 99 in the main regressions. We find that the results are robust. In particular, the probability of an SEO is $50.5 \%$ higher ( $p$-value $<0.01)$, insider sales are $7.2 \%$ higher ( $p$-value $<0.01$ ), and the probability of a stock-based acquisition is $26.8 \%$ higher $(p$-value $<0.01)$ in the four quarters following IBP.

(ii) Our hypotheses contrast IBP stocks with all other stocks. The rest of the stocks include WBP stocks, and we do not separately control for a WBP indicator in our main tests. WBP stocks are subject to widespread mutual fund buying pressure, which potentially reflects favorable information about these firms and their investment opportunities. Thus, it is quite likely that WBP is positively correlated with future SEOs and acquisitions. Such correlation may arise due to the relatively favorable investment opportunities of WBP firms (Table III and Figure 1 suggest that WBP stocks are not overvalued since there is no return reversion after WBP). As an extension of our benchmark specification, we include an indicator variable for WBP. We use this indicator to absorb some of the unexplained variation in the dependent variable across the sample of non-IBP stocks. The results are robust to including an indicator for WBP stocks. In particular, the probability of an SEO is $58.6 \%$ higher $(p$-value $<0.01)$, insider sales are $7.5 \%$ higher ( $p$-value $<0.01)$, and the probability of a stock-based acquisition is $26.9 \%$ higher $(p$-value $<0.01)$ in the four quarters following IBP.

(iii) We use both newly initiated holdings and expansions of existing holdings by high inflow funds to identify IBP stocks. An argument for price pressure associated with investment 
constraints applies more naturally to funds' existing holdings as opposed to newly initiated positions. We therefore modify Pressure to sum increases in holdings by mutual funds in the top flow decile only if these increases are expansions of previously held positions, and not new initiations. The results are robust. Specifically, IBP stocks have cumulative market-adjusted returns of $-7.84 \%$ ( $p$-value $<0.01)$ over the six quarters following buying pressure. In addition, the probability of an SEO is $50 \%$ higher $(p$-value<0.01), insider sales are $5.4 \%$ higher $(p$ value $<0.01$ ), and the probability of an acquisition is $22 \%$ higher ( $p$-value $<0.01$ ) in the four quarters following buying pressure.

(iv) We identify IBP firms as those in the top decile of Pressure but in the middle three deciles of UPressure. Our objective in intersecting with the middle deciles of UPressure is to isolate stocks that are not being widely traded by all other mutual funds. Although symmetry considerations may dictate using the middle quintile of UPressure, we expand our sample of IBP stocks by including three middle deciles. As a robustness check, we replicate our key regressions while intersecting the top decile of Pressure with either the middle two or the middle four UPressure deciles. In both cases we find slightly stronger results. For the case of the middle two deciles of UPressure, we identify 1,523 IBP stock-quarters from 1990 to 2007, with cumulative abnormal returns of $-12.84 \%$ ( $p$-value $<0.05)$ over the six quarters following buying pressure. Furthermore, the probability of an SEO is $63 \%$ higher ( $p$-value $<0.01)$, insider sales are $6.9 \%$ higher ( $p$-value $<0.01)$, and the probability of an acquisition is $30 \%$ higher $(p$-value $<0.05)$ in the four quarters following buying pressure. For the case of the middle four deciles of UPressure, 
we identify 3,384 IBP stock-quarters from 1990 to 2007, with cumulative abnormal returns of $-7.9 \%$ ( $p$-value<0.01) over the six quarters following IBP. Furthermore, the probability of an SEO is $59 \%$ higher ( $p$-value $<0.01)$, insider sales are $7.5 \%$ higher ( $p$-value $<0.01)$, and the probability of an acquisition is $28 \%$ higher $(p$-value $<0.01)$ in the four quarters following IBP.

(v) We repeat the insider sale tests under an alternative definition of insiders as the top five executives: CEO, Chairman, President, $\mathrm{CFO}$ and $\mathrm{COO}$. The results are robust, with insider sales increasing by $6.6 \%(p$-value $<0.01)$ in the four quarters following IBP.

\section{Conclusion}

The prior literature examines the price impact of trades by mutual funds with large capital inflows and outflows. We find that stocks subject to buying pressure by mutual funds experiencing large capital inflows, but not subject to widespread buying pressure by other mutual

funds, experience a substantial upward price impact. Since we use widespread mutual fund buying pressure as an indicator of informed trading, this result suggests that stock prices change in response to uninformed shifts in demand.

Inflow-driven mutual fund buying pressure is a relatively exogenous overvaluation identifier for SEO timing studies because it is associated with who is buying - buyers with excess liquidity - rather than with what is being purchased. The price effects of mutual fund buying pressure are sufficiently long-lived to allow managers who are able to identify the overvaluation to time SEOs, insider sales, and stock-based acquisitions. We find that in the four 
quarters following the occurrence of flow-driven buying pressure, the probability of an SEO is $59 \%$ higher, insider sales are $7 \%$ higher, and the probability of completion of a stock-based acquisition is $20 \%$ higher. These results suggest that firm managers are able to identify and exploit overvaluation.

Our evidence of a long-lived price impact of uninformed demand shifts, while consistent with empirical evidence in Coval and Stafford (2007) and the arguments of Shleifer (1986), is intriguing. One possible conclusion is that arbitrage was unsuccessful at flattening the demand curve. Reasons for limits to arbitrage include the unavailability of close substitutes, specialization among arbitrageurs combined with a limited number of arbitrageurs, lingering differences in investor opinion about the true value of the stock, and short sales constraints. Alternatively, as Coval and Stafford (2007) point out, market participants may have been unaware of the return pattern induced by mutual fund flows because the relevant data was not available at the time. As we show, despite the data limitations, some firm managers are able to identify overvaluation in the equity of their own firm and react to it by issuing additional shares or selling shares from their personal account. The persistence of the price impact presents an opportunity for future research.

Our findings have a number of additional implications for future research. First, in an international context, smaller markets with fewer close substitutes for individual stocks may experience a greater price impact from uninformed shifts in demand, which suggests that the patterns of predictability that we identify may be even stronger in such markets. Second, the possibility of persistent stock price dislocation due to uninformed demand shifts has implications 
for managerial performance evaluation and the optimal sensitivity of managerial compensation to short-run stock returns. Third, from a corporate governance perspective, our findings suggest that managers are sometimes better informed than the market and are able to identify market misvaluations, which has implications for the level of discretion they are allowed in responding to price movements through a variety of corporate decisions. Other research opportunities include examining the bond price impact of mutual fund trading pressure and the likelihood of subsequent debt issuances, and examining the effect of mutual fund trading pressure on the use of cash versus stock in corporate acquisitions. 


\section{Appendix: Variable Definitions}

Asset growth is the change in the log of total assets from the same quarter in the previous year.

$B T M$ is book value of shareholders' equity over market value of equity.

BTM1 to BTM10 are deciles of BTM, from BTM1 (low BTM) to BTM10 (high BTM).

Cash is cash and short-term investments over total assets.

Dividend yield is the dividend per share divided by the stock price.

Insider Holding is the number of shares held by insiders scaled by total shares outstanding.

Insider Sale is the ratio of shares sold by all insiders to the sum of shares sold and purchased by

all insiders in a firm-quarter.

Leverage is long-term debt plus long-term debt in current liabilities, over total assets.

Pressure is defined in equation (2) in Section II in the text.

1-year Return is the stock return over the prior year.

$R O A$ is operating income before depreciation over total assets.

Size is the natural logarithm of total assets.

UPressure is defined in equation (3) in Section II in the text.

Volatility is the standard deviation of daily stock returns over the quarter.

$\Delta$ Volatility is the change in volatility from the same quarter in the previous year. 


\section{References}

Asquith, Paul, and David Mullins, 1986, Equity issues and offering dilution, Journal of Financial Economics 15, 61-89.

Baker, Malcolm, Richard Ruback, and Jeffrey Wurgler, 2007, Behavioral corporate finance: A survey, in Espen Eckbo, ed.: Handbook in Corporate Finance: Empirical Corporate Finance (North Holland/Elsevier).

Baker, Malcolm, Jeremy Stein, and Jeffrey Wurgler, 2003, When does the market matter? Stock prices and the investment of equity-dependent firms, Quarterly Journal of Economics 118, 9691005.

Baker, Malcolm, and Jeffrey Wurgler, 2002, Market timing and capital structure, Journal of Finance 57, 1-32.

Bettis, Carr, Jeffrey Coles, and Michael Lemmon, 2000, Corporate policies restricting trading by insiders, Journal of Financial Economics 57, 191-220.

Chen, Joseph, Samuel Hanson, Harrison Hong, and Jeremy Stein, 2007, Do hedge funds profit from mutual-fund distress? Working paper, University of California, Davis.

Chevalier, Judith, and Glenn Ellison, 1997, Risk taking by mutual funds as a response to incentives, Journal of Political Economy 105, 1167-1200.

Core, John, Wayne Guay, Scott Richardson, and Rodrigo Verdi, 2006, Stock market anomalies: What can we learn from repurchases and insider trading? Review of Accounting Studies 11, 4970 .

Coval, Joshua, and Erik Stafford, 2007, Asset firesales (and purchases) in equity markets, Journal of Financial Economics 86, 479-512.

DeAngelo, Harry, Linda DeAngelo, and Rene Stulz, 2010, Seasoned equity offerings, market timing, and the corporate life cycle, Journal of Financial Economics 95, 275-295.

Eckbo, B. Espen, and Ronald Masulis, 1992, Adverse selection and the rights offer paradox, Journal of Financial Economics 32, 293-322.

Eckbo, B. Espen, Ronald Masulis, and Oyvind Norli, 2000, Seasoned public offerings: Resolution of the new issues puzzle, Journal of Financial Economics 56, 251-292. 
Fama, Eugene, and Kenneth French, 1993, Common risk factors in the returns on stocks and bonds, Journal of Financial Economics 33, 3-56.

Fama, Eugene, and Kenneth French, 2005, Financing decisions: Who issues stock? Journal of Financial Economics 76, 549-582.

Fama, Eugene, and James MacBeth, 1973, Risk, return, and equilibrium: Empirical tests, Journal of Political Economy 81, 607-636.

Frazzini, Andrea, and Owen Lamont, 2008, Dumb money: Mutual fund flows and the crosssection of stock returns, Journal of Financial Economics 88, 299-322.

Gao, Xiaohui, and Jay Ritter, 2010, The marketing of seasoned equity offerings, Journal of Financial Economics 97, 33-52.

Graham, John, and Campbell Harvey, 2001, The theory and practice of corporate finance: Evidence from the field, Journal of Financial Economics 60, 187-243.

Greenwood, Robin, 2005, Short- and long-term demand curves for stocks: Theory and evidence on the dynamics of arbitrage, Journal of Financial Economics 75, 607-649.

Harford, Jarrod, 1999, Corporate cash reserves and acquisitions, Journal of Finance 54, 19691997.

Harris, Lawrence, and Eitan Gurel, 1986, Price and volume effects associated with changes in the S\&P 500 list: New evidence for the existence of price pressures, Journal of Finance 41, 815829.

Ippolito, Richard, 1992, Consumer reaction to measures of poor quality: Evidence from the mutual fund industry, Journal of Law and Economics 35, 45-70.

Jensen, Michael, 1986, Agency costs of free cash flow, corporate finance, and takeovers, American Economic Review 76, 323-329.

Jensen, Michael, 2005, Agency costs of overvalued equity, Financial Management 34, 5-19.

Jenter, Dirk, 2005, Market timing and managerial portfolio decisions, Journal of Finance 60, 1903-1949.

Kraus, Alan, and Hans Stoll, 1972, Price impacts of block trading on the New York Stock Exchange, Journal of Finance 27, 569-588. 
Lakonishok, Josef, Andrei Shleifer, and Robert Vishny, 1992, The impact of institutional trading on stock prices, Journal of Financial Economics 32, 23-44.

Loughran, Tim, and Jay Ritter, 1995, The new issues puzzle, Journal of Finance 50, 23-51.

Loughran, Tim, and Jay Ritter, 1997, The operating performance of firms conducting seasoned equity offerings, Journal of Finance 52, 1823-1850.

Mitchell, Mark, Todd Pulvino, and Erik Stafford, 2004, Price pressure around mergers, Journal of Finance 59, 31-63.

Petersen, Mitchell, 2009, Estimating standard errors in finance panel data sets: comparing approaches, Review of Financial Studies 22, 435-480.

Piotroski, Joseph, and Darren Roulstone, 2005, Do insider trades reflect both contrarian beliefs and superior knowledge about future cash flow realizations? Journal of Accounting and Economics 39, 55-82.

Rhodes-Kropf, Matthew, and S. Viswanathan, 2004, Market valuation and merger waves, Journal of Finance 59, 2685-2718.

Rhodes-Kropf, Matthew, David Robinson, and S. Viswanathan, 2005, Valuation waves and merger activity: The empirical evidence, Journal of Financial Economics 77, 561-603.

Rozeff, Michael, and Mir Zaman, 1988, Market efficiency and insider trading: New evidence, Journal of Business 61, 25-44.

Rozeff, Michael, and Mir Zaman, 1998, Overreaction and insider trading: Evidence from growth and value portfolios, Journal of Finance 53, 701-716.

Seyhun, H. Nejat, 1986, Insider profits, costs of trading, and market efficiency, Journal of Financial Economics 16, 189-212.

Shleifer, Andrei, 1986, Do demand curves for stocks slope down? Journal of Finance 41, 579590.

Shleifer, Andrei, and Robert Vishny, 2003, Stock market driven acquisitions, Journal of Financial Economics 70, 295-311. 
Sirri, Erik, and Peter Tufano, 1998, Costly search and mutual fund flows, Journal of Finance 53, 1589-1622.

Wermers, Russ, 1999, Mutual fund herding and the impact on stock prices, Journal of Finance 59, 581-622. 
Table I:

Mutual Fund Flow Predictability and Prior Performance

Mutual funds are sorted quarterly into deciles of capital flows. The sample consists of 63,426 fund-quarters from 1990 to 2007. Flow is calculated as as $\left\{T A_{j, s}-T A_{j, s-1}\left(1+R_{j, s-1}\right)\right\} / T A_{j, s-1}$, where $T A$ is total net assets of mutual fund $j$ in month $s$, and $R$ is the quarterly return for fund $j$ in month $s$. Monthly flows are summed to obtain the quarterly flow, flow $w_{j, t}$, of mutual fund $j$ in quarter $t$. Prior Fund Return is the fund return in the last year. Avg \# Holdings is the average number of stocks in a fund-quarter. \% Holdings Expanded is the percent of stocks held in quarter $t$ that were held in $t-1$ and in which the fund increased its holdings. \% Holdings Initiated is the percent of stocks held in quarter $t$ that were not held in $t-1$

\begin{tabular}{|c|c|c|c|c|c|}
\hline$\underline{\text { Flow Decile }}$ & $\underline{\text { Flow }}$ & $\underline{\text { Prior Fund Return }}$ & $\underline{\text { Avg \# Holdings }}$ & \% Holdings Expanded & \% Holdings Initiated \\
\hline Inflow & $40.3 \%$ & $16.6 \%$ & 107 & $39 \%$ & $19 \%$ \\
\hline 9 & $14.1 \%$ & $14.6 \%$ & 122 & $34 \%$ & $17 \%$ \\
\hline 8 & $7.0 \%$ & $13.2 \%$ & 149 & $31 \%$ & $16 \%$ \\
\hline 7 & $3.3 \%$ & $12.1 \%$ & 145 & $26 \%$ & $16 \%$ \\
\hline 6 & $1.0 \%$ & $11.0 \%$ & 144 & $23 \%$ & $16 \%$ \\
\hline 5 & $-0.7 \%$ & $9.8 \%$ & 126 & $20 \%$ & $16 \%$ \\
\hline 4 & $-2.3 \%$ & $9.1 \%$ & 117 & $19 \%$ & $17 \%$ \\
\hline 3 & $-4.1 \%$ & $7.8 \%$ & 106 & $18 \%$ & $18 \%$ \\
\hline 2 & $-6.8 \%$ & $6.3 \%$ & 99 & $18 \%$ & $19 \%$ \\
\hline Outflow & $-17.0 \%$ & $6.1 \%$ & 103 & $16 \%$ & $20 \%$ \\
\hline
\end{tabular}




\section{Table II:}

\section{Stock-level Means, and Tests of Differences in Means}

Table II reports means for the full sample, for the stocks subject to inflow-driven buying pressure (IBP sample), and for stocks subject to widespread buying pressure by all mutual funds other than funds in the top decile of capital flows (WBP sample). The full (IBP) [WBP] sample consists of $313,750(2,515)$ [17,160] stock-quarters from 1990 through 2007. IBP stocks are those in the top decile of Pressure, but in the middle three deciles of UPressure, in quarter $t=0$. WBP stocks are those in the top decile of UPressure in quarter $t=0$. Pressure is a stocklevel measure of flow-motivated trading by all mutual funds. UPressure is a measure of widespread trading by mutual funds that is not motivated by capital flows and is intended to capture information-motivated trading. All variable definitions are presented in the Appendix. The last three columns report tests of differences in means between the three samples. Differences in means are calculated each quarter for each pair of samples, and the time series of differences are used for statistical inference to control for cross-sectional correlation. ***, **, and * represent one-tailed statistical significance at less than the $1 \%, 5 \%$, and $10 \%$ level, respectively.

\begin{tabular}{|c|c|c|c|c|c|c|}
\hline & $\underline{\text { Full Sample }}$ & $\underline{\text { IBP Sample }}$ & $\underline{\text { WBP Sample }}$ & & & \\
\hline Variable & (1) & $(2)$ & (3) & $(1)-(2)$ & $(1)-(3)$ & $(2)-(3)$ \\
\hline$R O A$ & 0.017 & 0.030 & 0.032 & $*$ & $* *$ & \\
\hline 1 year Return & 0.183 & 0.493 & 0.319 & $* * *$ & $* * *$ & $* * *$ \\
\hline BTM & 0.669 & 0.489 & 0.534 & $* *$ & $*$ & \\
\hline Size & 5.342 & 6.259 & 6.231 & $* * *$ & $* * *$ & \\
\hline Leverage & 0.206 & 0.202 & 0.208 & & & \\
\hline Dividend yield & 0.004 & 0.002 & 0.003 & & & \\
\hline Cash & 0.167 & 0.198 & 0.177 & $*$ & & \\
\hline Volatility & 0.030 & 0.029 & 0.028 & & & \\
\hline$\Delta$ Volatility & 0.000 & -0.002 & -0.002 & & & \\
\hline Asset growth & 0.083 & 0.192 & 0.164 & $* * *$ & $* * *$ & \\
\hline Insider Sale & 0.400 & 0.483 & 0.462 & $* * *$ & $* * *$ & $* *$ \\
\hline Insider Holding & 0.025 & 0.016 & 0.015 & $* * *$ & $* * *$ & \\
\hline Pressure (\%) & 0.032 & 1.055 & 0.157 & $* * *$ & $* * *$ & $* * *$ \\
\hline Upressure (\%) & 0.375 & 0.685 & 9.676 & $*$ & $* * *$ & $* * *$ \\
\hline
\end{tabular}




\section{Table III: \\ Quarterly Abnormal Stock Returns due to Mutual Fund Buying Pressure}

Panel A shows mean quarterly abnormal returns from quarters $t-4$ to $t+6$ for stocks subject to mutual fund buying pressure in quarter $t=0$. Abnormal stock returns are industry-adjusted returns using the Fama-French equalweighted 48 industry portfolios. In Panel B, abnormal returns are the alphas (intercept) from calendar-time Fama and French (1993) three-factor regressions. The dependent variable in Panel B is the monthly excess return, over the risk-free rate, on a portfolio of IBP Stocks, and WBP Stocks, held for three years (upper panel) or five years (lower panel). Mkt-Rf, SMB and $H M L$ are the Fama-French factors. The alpha is in percentage points. IBP and WBP are described in the notes to Table II. The IBP (WBP) sample consists of 2,515 $(17,160)$ stock-quarters from 1990 through 2007. All variable definitions are presented in the Appendix. In Panel A, mean abnormal returns are calculated each quarter for the portfolio of IBP stocks and WBP stocks, and the time series of portfolio abnormal returns are used for statistical inference to control for cross-sectional correlation. ***, **, and * represent one-tailed statistical significance at less than the $1 \%, 5 \%$, and $10 \%$ level, respectively.

\begin{tabular}{|c|c|c|}
\hline \multicolumn{3}{|c|}{ Panel A: Industry-adjusted Returns } \\
\hline Quarter & IBP Stocks & WBP Stocks \\
\hline$t-4$ & $1.99 \%{ }^{* *}$ & $2.33 \%{ }^{* * *}$ \\
\hline$t-3$ & $3.53 \%{ }^{* * *}$ & $2.24 \%{ }^{* * *}$ \\
\hline$t-2$ & $2.29 \%{ }^{* *}$ & $2.64 \%{ }^{* * *}$ \\
\hline$t-1$ & $2.82 \%{ }^{* *}$ & $3.22 \%{ }^{* * *}$ \\
\hline$t=0$ & $5.12 \%{ }^{* * *}$ & $2.57 \%{ }^{* * *}$ \\
\hline$t+1$ & $-3.10 \%{ }^{* * *}$ & $-0.23 \%$ \\
\hline$t+2$ & $-1.11 \%$ & $-0.80 \% *$ \\
\hline$t+3$ & $-2.19 \%{ }^{* * *}$ & $-0.52 \%$ \\
\hline$t+4$ & $-1.55 \%{ }^{* *}$ & $-0.29 \%$ \\
\hline$t+5$ & $-1.41 \%{ }^{*}$ & $-0.61 \%$ \\
\hline$t+6$ & $-0.45 \%$ & $-0.23 \%$ \\
\hline$[t+1, t+6]$ & $-9.82 \%{ }^{* * *}$ & $-2.68 \%{ }^{*}$ \\
\hline
\end{tabular}

Panel B: Fama-French Alphas ( $\alpha$ )

\begin{tabular}{|c|c|c|}
\hline 3-year & $\underline{\mathrm{IBP}}$ & $\underline{\mathrm{WBP}}$ \\
\hline$\alpha$ & -0.36 ** & $-\overline{-0.08}$ \\
\hline$M k t-R f$ & $1.3^{* * *}$ & $1.21^{* * *}$ \\
\hline$S M B$ & $0.68^{* * *}$ & $0.61^{* * *}$ \\
\hline$H M L$ & 0.07 & $0.33^{* * *}$ \\
\hline Adj. $R^{2}$ & $86 \%$ & $88 \%$ \\
\hline
\end{tabular}


5-year

$\alpha$

$M k t-R f$

$S M B$

$H M L$

Adj. $\mathrm{R}^{2}$

$$
\begin{aligned}
& -0.31^{* *} \\
& 1.28^{* * *} \\
& 0.66^{* * *} \\
& 0.12^{*}
\end{aligned}
$$

$87 \%$
$-0.04$

$1.19^{* * * *}$

$0.61^{* * *}$

$0.34^{\text {*** }}$

$88 \%$ 
Table IV:

\section{Timing Seasoned Equity Offerings}

Panel A reports coefficients from logit regressions of the equity issuance choice on the independent variables shown. The dependent variable is one if the firm has a seasoned equity offering (SEO) in quarter $t$, and zero otherwise. Buy Pressure is a dummy that equals one if the stock was subject to IBP in any of the four quarters from $t-1$ to $t-4$, and zero otherwise. IBP is described in the notes to Table II. All variable definitions are presented in the Appendix. The second column shows results for the full sample. The last three columns show results for matched samples in which IBP stock-quarters are first matched on \{quarter, industry, first matching variable, second matching variable\}, where the first and second matching variables are indicated at the top of the column. Once the matched sample is obtained, a Logit regression is estimated with the same dependent and independent variables as for the full sample regression. Standard errors are clustered on both firm and time (twodimensional clustering), and the samples span 1990 through 2007. ***,**, and * represent one-tailed statistical significance at less than the $1 \%, 5 \%$, and $10 \%$ level, respectively. Panel B reports SEO frequencies in all three matched samples. In Panel B, SEO equals one for stockquarters with an SEO, and zero otherwise, while IBP equals one if the stock was subject to IBP in any of the quarters from $t$ - 1 to $t$ - 4 , and zero otherwise. The $p$-value in Panel B is from a test of difference in SEO relative frequencies when IBP equals one versus zero.

Panel A: SEO Logit Regression Coefficients

\begin{tabular}{|c|c|c|c|c|}
\hline \multirow[b]{2}{*}{ Variable } & \multirow[t]{2}{*}{ Full Sample } & \multicolumn{3}{|c|}{ Matched Samples } \\
\hline & & BTM-Size & Return-Size & AssetGrowth-ROA \\
\hline Intercept & $-6.077^{* * *}$ & $-4.163^{* * *}$ & $-4.086^{* * *}$ & $-4.633^{* * *}$ \\
\hline Buy Pressure & $0.461^{* * *}$ & $0.403^{* * *}$ & $0.260^{* *}$ & $0.607^{* * *}$ \\
\hline$R O A_{t-4}$ & -0.105 & $-2.413^{* *}$ & $-3.406^{* * *}$ & $-2.754^{* * *}$ \\
\hline Cash $_{t-4}$ & $0.689^{* * * *}$ & $0.512^{*}$ & 0.404 & 0.471 \\
\hline 1 year Return & $0.482^{* * *}$ & $0.459^{* * *}$ & $0.494^{* * *}$ & $0.364^{* * *}$ \\
\hline Size $_{t-4}$ & $0.177^{* * *}$ & $-0.115^{* * *}$ & $-0.077^{*}$ & -0.059 \\
\hline$B T M_{t-4}$ & $-0.532^{* * *}$ & -0.111 & $-0.592^{* * *}$ & $-0.458^{* * *}$ \\
\hline Leverage $_{t-4}$ & $0.564^{* * * *}$ & $1.348^{* * * *}$ & $1.162^{* * * *}$ & $1.141^{* * *}$ \\
\hline Dividend yield $_{t-4}$ & $-15.178^{* * * *}$ & -28.904 & -0.204 & -1.265 \\
\hline Volatility $_{t-4}$ & $14.659^{* * *}$ & 0.335 & 1.542 & 3.318 \\
\hline$\Delta$ Volatility $_{t, t-4}$ & -0.611 & $-15.033^{* * * *}$ & $-12.524^{* *}$ & $-12.550^{* *}$ \\
\hline Asset growth & $0.421^{* * * *}$ & 0.225 & $0.271^{*}$ & $0.397^{* * *}$ \\
\hline Time f.e. & Yes & Yes & Yes & Yes \\
\hline Industry f.e. & Yes & Yes & Yes & Yes \\
\hline $\operatorname{Adj} R^{2}$ & $9.4 \%$ & $8.3 \%$ & $9.2 \%$ & $7.7 \%$ \\
\hline
\end{tabular}




\begin{tabular}{|c|c|c|c|c|}
\hline \multicolumn{5}{|c|}{ Panel B: SEO Frequencies } \\
\hline \multirow[b]{2}{*}{ SEO } & \multirow[b]{2}{*}{$I B P$} & \multicolumn{3}{|c|}{ Matched Samples } \\
\hline & & BTM-Size & Return-Size & AssetGrowth-ROA \\
\hline 0 & 0 & 8202 & 8202 & 8230 \\
\hline 0 & 1 & 8146 & 8157 & 8163 \\
\hline 1 & 0 & 108 & 119 & 95 \\
\hline 1 & 1 & 164 & 164 & 162 \\
\hline$p$-value & & $<0.01$ & $<0.01$ & $<0.01$ \\
\hline
\end{tabular}


Table V:

\section{Timing Insider Sales}

Panel A reports coefficients from regressions of insider sales (Insider Sale) in quarter $t$ on the independent variables shown. Buy Pressure is a dummy that equals one if the stock was subject to IBP in any of the four quarters from $t$ - 1 to $t$-4, and zero otherwise. IBP is described in the notes to Table II. All variable definitions are presented in the Appendix. The second column shows results for the full sample. The last three columns show results for matched samples in which IBP stock-quarters are first matched on \{quarter, industry, first matching variable, second matching variable\}, where the first and second matching variables are indicated at the top of the column. Once the matched sample is obtained, a regression is estimated with the same dependent and independent variables as for the full sample regression. Standard errors are clustered on both firm and time (two-dimensional clustering), and the samples span 1990 through 2007. ***, **, and * represent one-tailed statistical significance at less than the 1\%, 5\%, and 10\% level, respectively. Panel B reports mean insider sales in all three matched samples. In Panel B, IBP equals one if the stock was subject to IBP in any of the quarters from $t-1$ to $t$-4, and zero otherwise. The $p$-value in Panel B is from a test of difference in mean insider sales when IBP equals one versus zero.

Panel A: Insider Sale Regression Coefficients

\begin{tabular}{|c|c|c|c|c|}
\hline \multirow[b]{2}{*}{ Variable } & \multirow[t]{2}{*}{ Full Sample } & \multicolumn{3}{|c|}{ Matched Samples } \\
\hline & & BTM-Size & Return-Size & Size-InsiderSale $_{t-1}$ \\
\hline Intercept & $0.247^{* * *}$ & $0.214^{* * *}$ & $0.218^{\text {**** }}$ & $0.184^{* * *}$ \\
\hline Buy pressure & $0.027^{* * *}$ & $0.021^{* * *}$ & $0.025^{* * *}$ & $0.025^{* * *}$ \\
\hline Size $_{t-4}$ & $0.008^{* * *}$ & $0.009^{* * *}$ & $0.008^{* * *}$ & $0.011^{* * *}$ \\
\hline Insider Sale $_{t-4}$ & $0.170^{* * *}$ & $0.181^{* * *}$ & $0.192^{* * *}$ & $0.176^{* * *}$ \\
\hline 1 year Return & $0.062^{* * *}$ & $0.063^{* * *}$ & $0.061^{* * *}$ & $0.060^{* * *}$ \\
\hline Volatility $_{t-4}$ & $-0.902^{* * *}$ & -0.071 & -0.133 & -0.009 \\
\hline$\Delta$ Volatility $_{t, t-4}$ & $-1.674^{* * *}$ & $-2.172^{* * *}$ & $-2.164^{* * *}$ & $-2.173^{* * *}$ \\
\hline BTM1 & $0.094^{* * *}$ & $0.090^{* * *}$ & $0.093^{* * *}$ & $0.101^{* * *}$ \\
\hline BTM2 & $0.099^{* * *}$ & $0.094^{* * *}$ & $0.091^{* * *}$ & $0.108^{* * *}$ \\
\hline BTM3 & $0.088^{* * *}$ & $0.067^{* * *}$ & $0.056^{* * *}$ & $0.084^{* * *}$ \\
\hline BTM4 & $0.078^{* * *}$ & $0.070^{* * *}$ & $0.079^{* * *}$ & $0.086^{* * *}$ \\
\hline ВТМ6 & $0.056^{* * *}$ & $0.043^{* *}$ & $0.052^{* * *}$ & $0.064^{* * *}$ \\
\hline ВTM7 & $0.043^{* * *}$ & 0.031 & $0.036^{* *}$ & $0.048^{* * *}$ \\
\hline ВТМ8 & $0.026^{* * *}$ & 0.024 & 0.021 & $0.032^{*}$ \\
\hline ВТМ9 & $0.025^{* * *}$ & 0.014 & 0.013 & $0.031^{*}$ \\
\hline
\end{tabular}




\begin{tabular}{|c|c|c|c|c|}
\hline Insider Holding & $0.373^{* * *}$ & $0.716^{* * *}$ & $0.747^{* * *}$ & $0.909^{* * *}$ \\
\hline Time f.e. & Yes & Yes & Yes & Yes \\
\hline Industry f.e. & Yes & Yes & Yes & Yes \\
\hline Adj $R^{2}$ & $8.82 \%$ & $7.31 \%$ & $8.00 \%$ & $7.81 \%$ \\
\hline $\mathrm{N}$ & 211227 & 13526 & 13590 & 13596 \\
\hline \multicolumn{5}{|c|}{ Panel B: Mean Insider Sales } \\
\hline & \multicolumn{4}{|c|}{ Matched Samples } \\
\hline IBP & BTM-Size & Return-Size & $\mathrm{Siz}$ & \\
\hline 0 & 0.438 & 0.427 & & \\
\hline 1 & 0.467 & 0.466 & & \\
\hline$p$-value & $<0.01$ & $<0.01$ & & \\
\hline
\end{tabular}


Table VI:

\section{Timing Acquisitions}

Panel A reports coefficients from logit regressions of the acquisition choice on the independent variables shown. The dependent variable is one if the firm engages in a stock-based acquisition in quarter $t$, and zero otherwise. Buy Pressure is a dummy that equals one if the stock was subject to IBP in any of the four quarters from $t-1$ to $t$-4. IBP is described in the notes to Table II. All variable definitions are presented in the Appendix. The second column shows results for the full sample. The last three columns show results for matched samples in which IBP stockquarters are first matched on \{quarter, industry, first matching variable, second matching variable\}, where the first and second matching variables are indicated at the top of the column. Once the matched sample is obtained, a Logit regression is estimated with the same dependent and independent variables as for the full sample regression. Standard errors are clustered on both firm and time (two-dimensional clustering), and the samples span 1990 through 2007. ***,**, and * represent one-tailed statistical significance at less than the 1\%, 5\%, and 10\% level, respectively. Panel B reports acquisition frequencies in all three matched samples. In Panel B, M\&A equals one for stock-quarters with an acquisition, and zero otherwise, while IBP equals one if the stock was subject to IBP in any of the quarters from $t-1$ to $t-4$, and zero otherwise. The $p$-value in Panel B is from a test of difference in relative acquisition frequencies when IBP equals one versus zero.

Panel A: M\&A Logit Regression Coefficients

\begin{tabular}{|c|c|c|c|c|}
\hline \multirow[b]{2}{*}{ Variable } & \multirow[t]{2}{*}{ Full Sample } & \multicolumn{3}{|c|}{ Matched Samples } \\
\hline & & BTM-Size & Return-Size & AssetGrowth-ROA \\
\hline Intercept & $-4.891^{\text {*** }}$ & $-5.120^{* * *}$ & $-5.188^{* * *}$ & $-5.279^{* * *}$ \\
\hline Buy pressure & $0.183^{* * *}$ & 0.114 & 0.098 & $0.218^{* *}$ \\
\hline 1 year Return & $0.255^{* * *}$ & $0.251^{* * *}$ & $0.228^{* * *}$ & $0.250^{* * *}$ \\
\hline Size $_{t-4}$ & $0.175^{* * *}$ & $0.138^{* * *}$ & $0.153^{* * *}$ & $0.153^{* * *}$ \\
\hline$B T M_{t-4}$ & $-0.749^{* * *}$ & $-0.585^{* * *}$ & $-0.557^{* * *}$ & $-0.638^{* * *}$ \\
\hline$R O A_{t-4}$ & 0.265 & $2.714^{* * *}$ & $1.756^{*}$ & $2.755^{* * *}$ \\
\hline $\operatorname{Cash}_{t-4}$ & $0.374^{* * *}$ & 0.177 & 0.156 & -0.023 \\
\hline Dividend yield $_{t-4}$ & $-6.202^{* *}$ & 12.246 & $11.796^{*}$ & 8.134 \\
\hline Volatility $_{t-4}$ & $2.992^{*}$ & $19.161^{* * *}$ & $18.819^{* * *}$ & $18.846^{* * *}$ \\
\hline$\Delta$ Volatility $_{t, t-4}$ & -0.276 & $12.138^{* * *}$ & 5.321 & $7.259^{* *}$ \\
\hline Asset growth & $0.438^{* * *}$ & $0.569^{* * *}$ & $0.644^{* * *}$ & $0.680^{* * *}$ \\
\hline Time f.e. & Yes & Yes & Yes & Yes \\
\hline Industry f.e. & Yes & Yes & Yes & Yes \\
\hline Adj $R^{2}$ & $7.2 \%$ & $4.7 \%$ & $4.7 \%$ & $6.1 \%$ \\
\hline $\mathrm{N}$ & 313750 & 16620 & 16642 & 16650 \\
\hline
\end{tabular}




\begin{tabular}{lcccc}
\hline \multicolumn{4}{c}{ Panel B: M\&A Frequencies } \\
\hline \multirow{2}{*}{ M\&A } & & \multicolumn{4}{c}{ Matched Samples } \\
\cline { 2 - 5 } 0 & $I B P$ & BTM-Size & Return-Size & AssetGrowth-ROA \\
0 & 0 & 8085 & 8108 & 8125 \\
1 & 1 & 8043 & 8056 & 8057 \\
1 & 0 & 225 & 213 & 200 \\
& 1 & 267 & 265 & 268 \\
$p$-value & & & & $<0.01$ \\
\hline
\end{tabular}




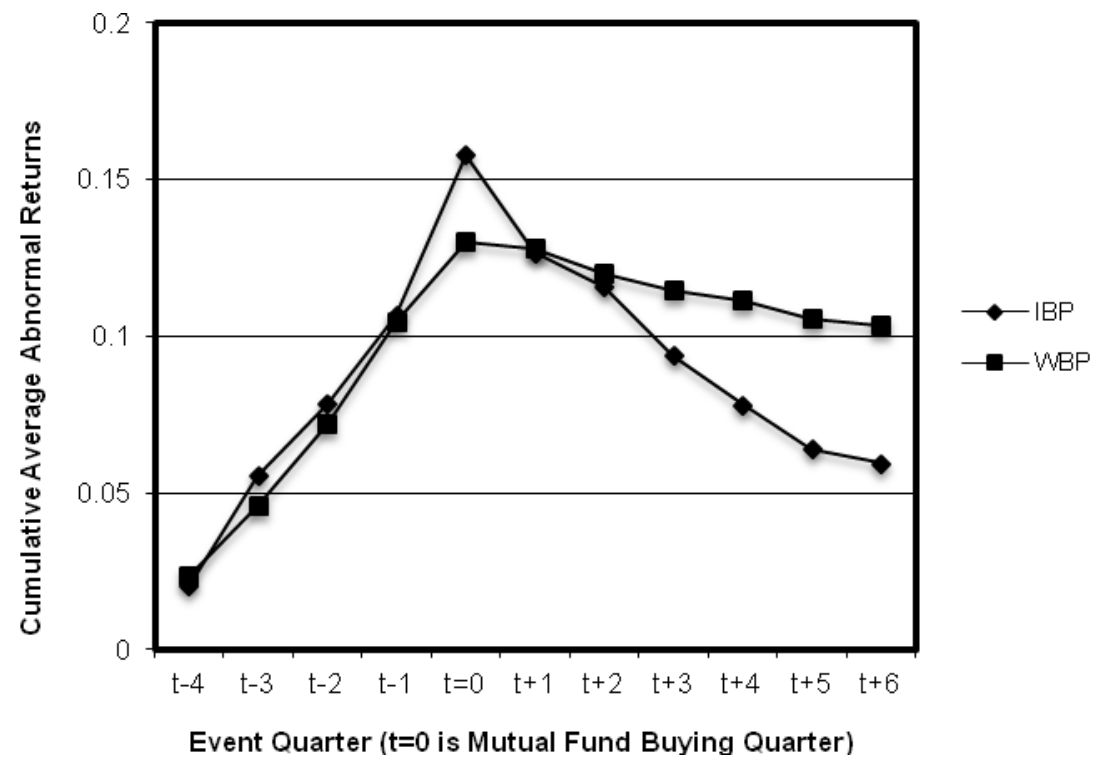

Figure 1. Stock-level abnormal returns due to mutual fund buying pressure. The figure shows cumulative average abnormal returns of stocks subject to buying pressure by mutual funds. Abnormal returns are industryadjusted returns, using the Fama-French equal-weighted 48 industry portfolios. We sum average quarterly abnormal returns to obtain the cumulative average abnormal returns. IBP and WBP are described in the notes to Table II. The IBP (WBP) sample consists of 2,515 (17,160) stock-quarters from 1990 through 2007. 